\title{
The Top-Viewed Cryosphere Videos on YouTube: An Overview
}

\author{
Adam Emmer ${ }^{1, * \mathbb{D}}$, Vojtěch Cuřín ${ }^{1}{ }^{\mathbb{D}}$, Jan Daněk ${ }^{1,2} \mathbb{D}^{\mathbb{D}}$, Helena Duchková ${ }^{1}$ and Petr Krpec ${ }^{1,3}$ \\ 1 The Czech Academy of Sciences, Global Change Research Institute, 60300 Brno, Czech Republic; \\ curin.v@czechglobe.cz (V.C.); danek.j@czechglobe.cz (J.D.); duchkova.h@czechglobe.cz (H.D.); \\ krpec.p@czechglobe.cz (P.K.) \\ 2 Faculty of Humanities, Charles University in Prague, 15800 Prague 5, Czech Republic \\ 3 Department of Physical geography and Geoecology, Faculty of Science, University of Ostrava, \\ 71000 Ostrava, Czech Republic \\ * Correspondence: aemmer@seznam.cz or emmer.a@czechglobe.cz
}

Received: 27 March 2019; Accepted: 16 April 2019; Published: 19 April 2019

\begin{abstract}
Youtube.com has become one of the most popular places to share videos on the Internet, storing a large amount of audiovisual materials. People all over the world can upload their videos and watch videos of others. The research potential of this information source has received increasing popularity across scientific disciplines. In this contribution, we explore the top viewed videos containing selected cryospheric keywords, both general (cryosphere, glacier, ice, permafrost, snow), and specific, focusing on different types of cryospheric hazards (avalanche, blizzard and glacial lake outburst flood/jokulhlaup). Searching 100 top-viewed videos for each keyword, our database consists of 859 videos. Each video is described by several qualitative characteristics (e.g., video type, geographical focus) as well as quantitative characteristics (e.g., views per day, likes). A total of 310 videos in our database ( $36.1 \%$ of all) are classified as videos with factual cryospheric content. We show that the broader audience represented by YouTube users is particularly interested in videos capturing dynamic processes such as calving of glaciers. While videos found for general cryosphere keywords have attracted a generally higher attention of YouTube users (total views), videos found for specific keywords are ranked among the most liked. Further, we analyze where the videos with cryospheric content are filmed, revealing several hotspots for different keywords located in all continents except for Africa. Finally, we discuss the potentials of cryosphere videos for educational and research purposes, pointing out that videos filmed by incidental witnesses of low-frequency processes such as glacial lake outburst floods might contribute to the elucidation of their dynamics, magnitude and behavior as well as the occurrence in space and time.
\end{abstract}

Keywords: YouTube; cryosphere; public interest; jokulhlaup; GLOFs; avalanche; blizzard; geosciences

\section{Introduction}

Climate change impacts the cryosphere more visibly than other parts of the Earth system [1], resulting in various geo-hydrological as well as ecological and societal consequences, bringing challenges outreaching the cryosphere [2]. As such, the cryosphere attracts substantial attention from scientists as well as policy- and decision-makers (e.g., [3-5]). On the other hand, only a limited amount of studies addresses the public perception of the cryosphere (in its broad sense), most frequently on local to regional scales. Among these, Garavaglia et al. [6] evaluated tourists' perception of environmental changes (including changes within the cryosphere) in the Italian Alps. The perception of climate change and associated changes in the cryosphere, as well as suitable adaptation options, have been researched in inland China by Deng et al. [7]. The cryosphere service function, aiming at 
the decision-makers' and public awareness of environmental protection, has been proposed by Xiao et al. [8]. Finally, Demiroglu et al. [9] investigated the visitors' perception of a shrinking glacier in a ski resort in Norway. Studies touching on the topic of the perception of glaciers and glacier-related risks have been performed in inhabited high mountain ranges of the world, among others in the Himalayas [10-12], and Andes [13-15]. These studies mainly investigated the impacts of climate change but also pointed out the spiritual significance of glaciers for local communities [16-18]. These studies frequently employed various methods involving communities and stakeholders, e.g., interviews and questionnaire surveys.

At the same time, with increasing availability, quantity and quality of recording devices and well-developed image processing systems, videos uploaded on the internet are gaining more interest. Such videos might be exploited for multiple scientific purposes, e.g., in citizen science (i.e., the public contribution to research design, data collection and knowledge [19]), especially while including temporal and spatial information [20-22].

There is a large volume of publications mentioning YouTube as a topic in the Web of Science (WoS) Core Collection Database [23]; specifically, there are 5357 total records up to date (March 2019). Since the first publications in 2006, the popularity of using YouTube for science has increased exponentially. Concurrently, the trend in the citation of the articles is also accelerating exponentially. YouTube is utilized across multiple disciplines with the most records in the WoS categories of computer sciences (51\%; computer science, software engineering, information systems, theory methods, artificial intelligence, interdisciplinary applications, hardware architecture, cybernetics). Videos are widely used for education ( $11.5 \%$ of total records; e.g., [24,25]), however, they may also contain valuable scientific data, which can benefit research [26].

Volunteered geographic information is commonly used in citizen science [27] and refers to information collected and shared by the public [28]. The use of citizen science is commonly employed in fields of natural sciences, e.g., ecology [29-31], although the volume of records in geosciences is scarce. Despite many researchers pointing out the unutilized source of user-uploaded data in geosciences, especially in regard to natural hazards [20,28], geo-categories (WoS categories of geosciences multidisciplinary, geography, geochemistry geophysics and geography physical) only represent $0.484 \%$ of the WoS-indexed publications mentioning YouTube. Previous research papers classified under geo-categories, for instance, have utilized YouTube for communication [32,33] or education $[25,34]$, however, there are very few papers using YouTube as a database for analysis. Klenner et al. [35] and Heipkie [36] reviewed the state of the use of citizen science in geosciences while highlighting the possible benefits for the field.

While we observe the apparently increasing popularity of using YouTube in the scientific articles, this has been rarely employed in geosciences, let alone a specific part of it, such as the cryosphere. The main objective of this study is to explore the top-viewed videos containing cryosphere keywords and the top-viewed videos with factual cryospheric content, revealing components of the cryosphere of particular interest for the broader public audience (represented by YouTube users). Further, we aim to explore the geographical distribution of these videos and discuss their use for educational and research purposes. This study gives a special emphasis on the different types of rapid cryospheric hazards, which are addressed in more detail.

\section{Materials and Methods}

\subsection{Keywords Definition and Database Building}

A total of nine keywords were selected to cover main streams of cryospheric science and to be in line with priorities of the Cryosphere II Special issue [37]. Five general terms used in the cryosphere science (cryosphere, glacier, ice, permafrost, snow) and four selected cryospheric hazards (avalanche, blizzard, glacial lake outburst flood (GLOFs), jokulhlaup) were used in this study since natural hazards are of special research interest [38]. Search for the keywords was conducted in the period of January to 
February 2019, using computers with a public IP address located in the Czech Republic; no access restrictions to the content have been experienced regarding the location or copyrights. However, we are aware that some of the content might not be accessible globally due to diverse country-specific restrictions and copyright policies, and we realize that: (i) These restrictions and policies might influence the overall statistics (e.g., total views if some content would be accessible globally while others would not); and (ii) applying the same methodology in different country-specific settings might lead to different results (e.g., different lists of the top-viewed videos). For each of the keywords defined, 100 top-viewed videos were sought at YouTube.com (as a signed-out user) and considered for the database. Fewer videos were considered for the keyword glacial lake outburst flood $(n=98)$ and jokulhlaup $(n=61)$ since there were no more results found at the time of the research. The database consists of 859 videos, of which few appear in the datasets of more than one keyword.

Each video considered in the database is described by several quantitative and qualitative characteristics (see Table 1). All information was gathered from YouTube.com-from the list of the most viewed videos (Views, Length) and from the pages of individual videos (Title, Author, Subscribers, Date published, Likes, Dislikes). Days since published were calculated as the difference between Date published and the date of the database building (in days); Views per day were calculated from Views divided by Days since published. The Type of the video and Geographical focus was assigned manually based on the title/description and visual interpretation of the content. It is important to note that the content of YouTube.com evolves dynamically and that our findings are valid at the time of database building (January/February 2019; see SUPPLEMENT).

Table 1. Characteristics used to describe each video in the database. The high variability of values documents apparent differences among different types of videos (e.g., music videos and videos with factual cryospheric content) and among keywords used (i.e., general and specific keywords).

\begin{tabular}{|c|c|c|}
\hline Characteristic & Description & Values \\
\hline Title & Title of the video & 843 unique titles (a total of 859 videos) \\
\hline Author & Name of YouTube channel & 661 unique YouTube channels \\
\hline Subscribers & Total of channel's subscribers & 0 to $66 \mathrm{M}$ subscribers of the channel \\
\hline Length & Duration of the video (h:m:s) & 0:00:04 to $10: 00: 10$ \\
\hline Date published & Date of appearance on YouTube & 4.3.2006-12.2.2019 \\
\hline Days since published & $\begin{array}{c}\text { Difference between Date published and the } \\
\text { date of analysis (in days) }\end{array}$ & 10-4720 days \\
\hline Views & Total views at the date of database building & $2-1.6 \mathrm{~B}$ views \\
\hline Views per day & An average number of views per day & $0.007-4,500,000$ views per day \\
\hline Likes & Total of likes (thumbs up) & $0-16 \mathrm{M}$ \\
\hline Dislikes & Total of dislikes (thumbs down) & $0-761,000$ \\
\hline Type & $\begin{array}{l}\text { Qualitative description of the content } \\
\text { (6 categories) }\end{array}$ & $\begin{array}{l}\text { (i) video with cryospheric content; } \\
\text { (ii) music video; (iii) movie; } \\
\text { (iv) gaming video; (v) sport video; } \\
\text { (vi) other }\end{array}$ \\
\hline Cryosphere keyword & Cryospheric keyword used in the search (9) & $\begin{array}{l}\text { (i) cryosphere; (ii) glacier; (iii) ice; } \\
\text { (iv) permafrost; (v) snow; } \\
\text { (vi) avalanche; (vii) blizzard; } \\
\text { (viii) glacial lake outburst flood; } \\
\text { (ix) jokulhlaup }\end{array}$ \\
\hline Geographical focus ${ }^{1}$ & Location where the video has been shot & $\begin{array}{l}27 \text { locations/hotspots in } 17 \\
\text { different countries }\end{array}$ \\
\hline
\end{tabular}

\subsection{Database Analysis and the Structure}

The first part of this study analyzes the entire database, focusing on the share of different video types among individual cryospheric keywords (Section 3.1). The Word cloud analysis has been employed using the MAXQDA 2018.2 software [39] to create word clouds highlighting the most frequently occurring words among video titles. Various types of word clouds have been previously successfully employed in the scientific papers [40-42]. In this study, only words appearing three or 
more times are considered. Single characters and letters, graphical icons, conjunctions, prepositions and articles were omitted from the word cloud analysis. The second part analyzes a subset of videos with factual cryospheric content, focusing on the most popular cryosphere components and geographical distribution (Section 3.2). ESRI ArcGIS version 10.6. has been used to visualize the locations of the videos' contents. The third part analyzes videos featuring selected cryospheric hazards in detail (Section 3.3). Further, we discuss the relationship between the quantitative characteristics-views, views per day, likes, dislikes and subscribers-using a linear regression model (see Section 4.2). Since values of individual variables differ in the order of magnitude (see Table 1), we use $\log 10$ transformation for the regression.

\section{The Top-Viewed Cryosphere Videos on YouTube}

\subsection{The Top-Viewed Videos Containing Cryosphere Keywords}

\subsubsection{General Characteristics of the Dataset}

This section documents information about the most viewed videos on YouTube for nine selected cryosphere keywords used and discusses the share of six different types of videos distinguished in this study (see Table 1). The most frequently represented type are videos with factual cryospheric content; a total of 310 videos out of 859 videos in the database (36.1\%) do have factual cryospheric content and are further analyzed in Sections 3.2 and 3.3. These are followed by music videos ( $n=224 ; 26.1 \%$ ) and gaming videos $(n=129 ; 15.0 \%)$. Sports videos and movies each represent about $5 \%$ in the database and videos classified as others represent the remaining $12.8 \%$. Figure 1 illustrates that a share of videos with factual cryospheric content varies considerably among the individual keywords used, reflecting their generality.
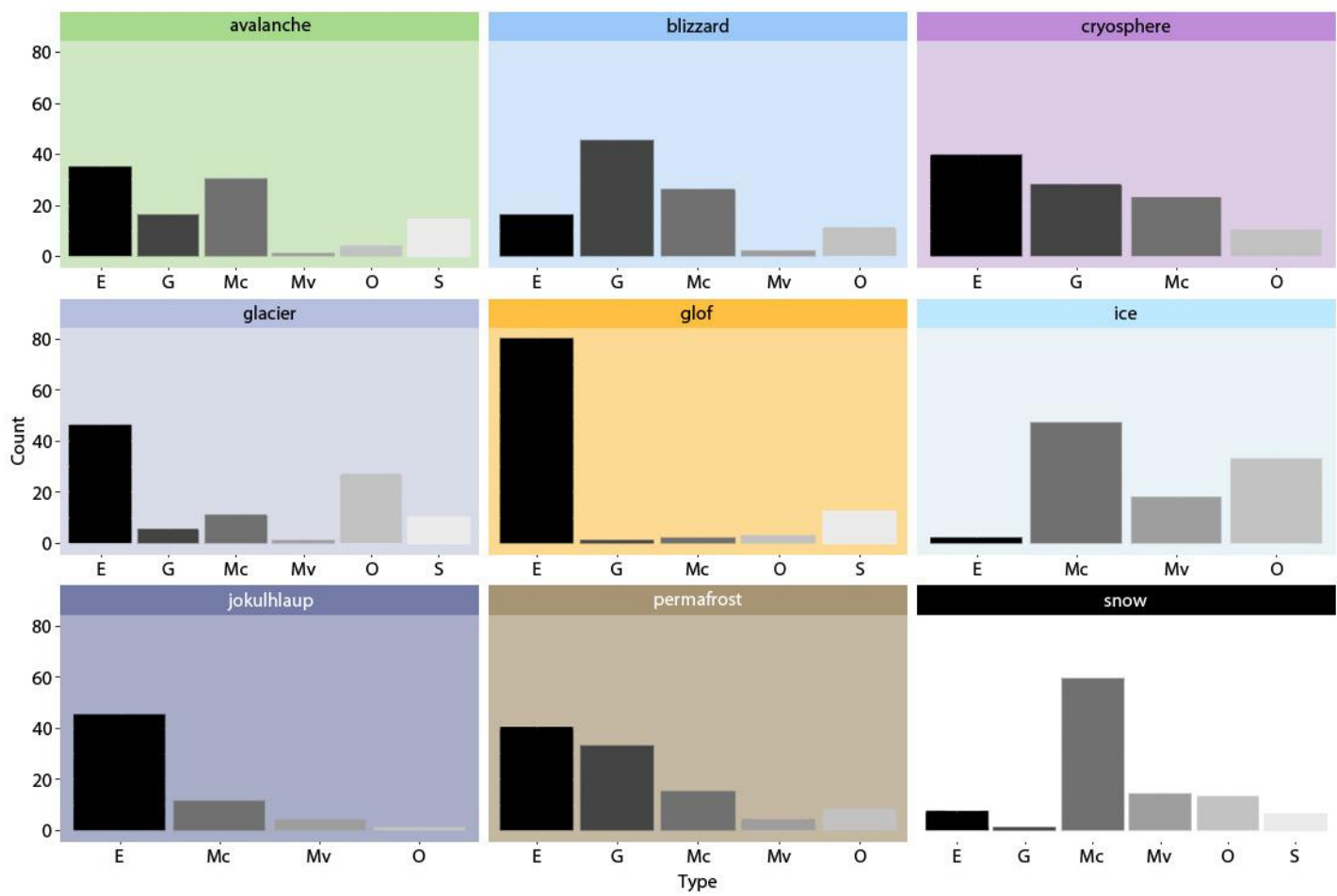

Figure 1. The share of different types of videos found for individual keywords (E-videos with factual cryospheric content; G-gaming videos; Mc—music videos; Mv—movies; S—sports videos; O—others). Note that the amount of videos found for glacial lake outburst flood (GLOFs) $(n=98)$ and jokulhlaups $(n=61)$ is lower compared to other keywords ( $n=100$ for each). 
The lowest share of videos with factual cryospheric content is observed for the keyword ice (2.0\%), and snow $(7.0 \%)$, while the highest is observed for glacial lake outburst floods $(81.6 \%)$. Apart from that, videos with cryospheric content also dominate the keyword avalanche $(35.0 \%)$, cryosphere $(39.0 \%)$, permafrost $(40.0 \%)$, glacier $(46.0 \%)$ and jokulhlaup $(73.8 \%)$, while music videos dominate the keyword snow $(59.0 \%)$ and ice $(47.0 \%)$ and gaming videos dominate the keyword blizzard $(45.0 \%$; see also Section 3.1.2).

Figure 2 shows the most frequently used words in the titles of top-viewed videos found for individual cryosphere keyword. "Cream" is the most repeated among the titles of videos found for the keyword ice (46.0\%), which is related to the high share of other music and movie videos (see also Figure 1), especially videos focusing on kids (e.g., ice cream color-learning videos such as Learn Colors with Yummy Ice Cream Cones Learn Colors for Children uploaded by the Yippee Toys channel). "Calving" is popular among videos found for the keyword glacier. "Patrol" (16.0\%) is the most popular word repeated in the titles of videos found for the keyword snow, apparently being linked to the high share of music videos among these (see Section 3.1.2). Similarly, "League" and "Legends" repeated in the titles of videos found for the keyword permafrost, which is related to the high share of gaming videos; also the word "Mighty" is frequent among the titles of videos found for the keyword cryosphere $(16.0 \%)$ and is related to the gaming videos. "Snowboarder", "Ski", "Accident" and "Survive" appear for the keyword avalanche. "Glacial", "Lake", "Outburst" and "Flood(s)" appear among the titles of videos found for the keyword jokulhlaup and vice versa, despite the fact that they are usually used for generically different processes in the scientific literature.
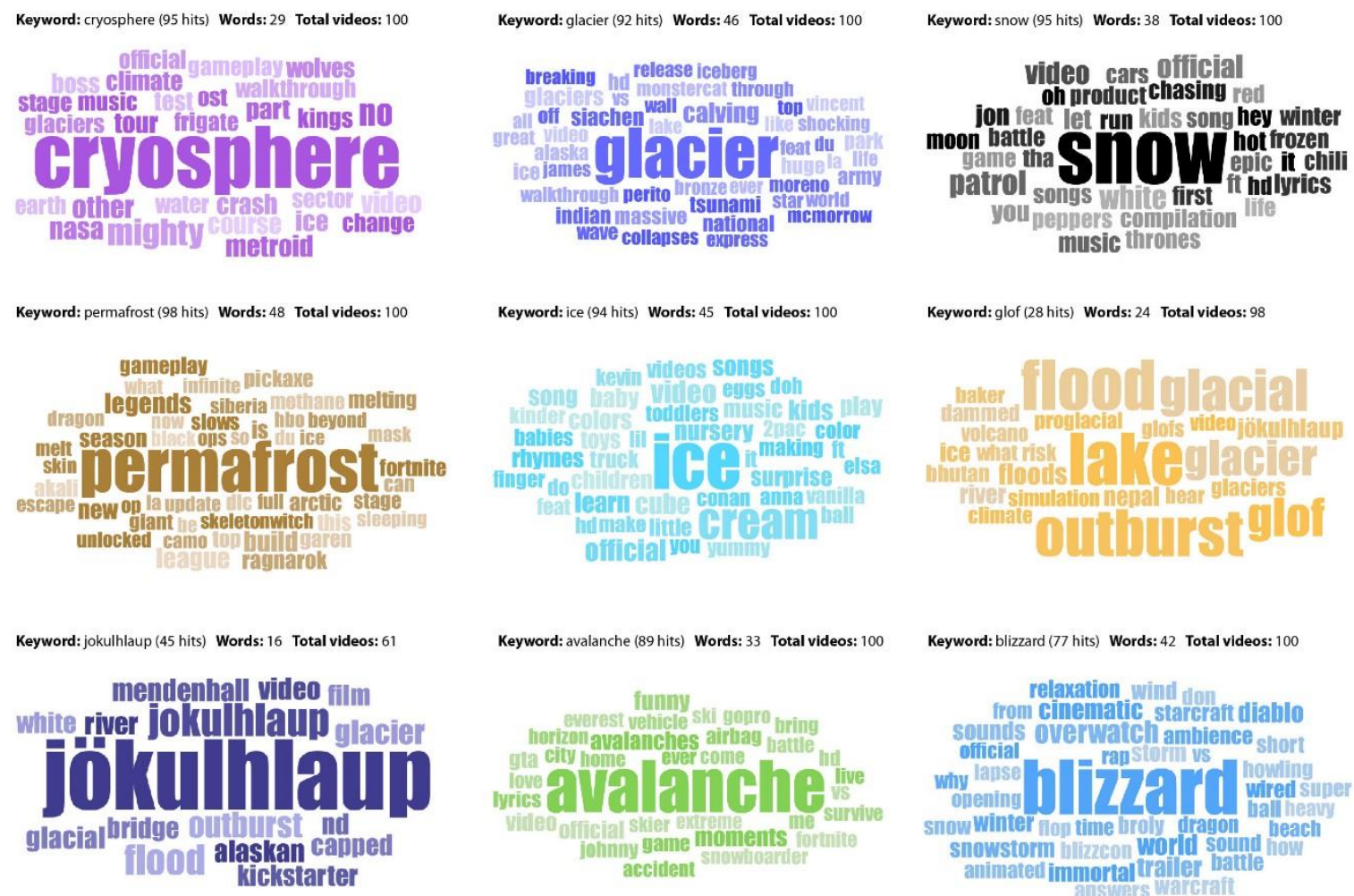

Keyword: avalanche (89 hits) Words: 33 Total videos: 100
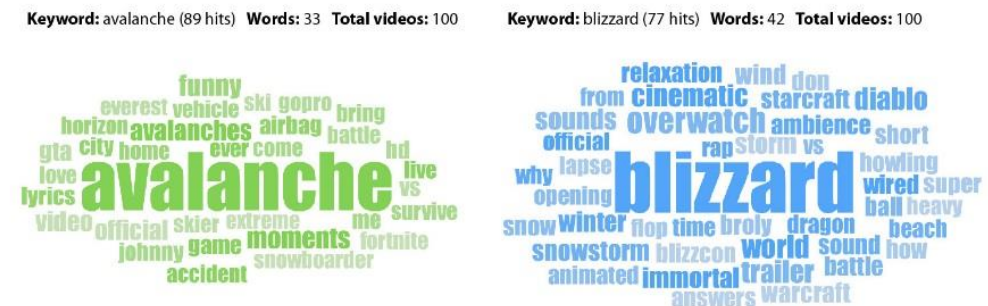

Figure 2. The most frequently used words in the titles of videos including individual cryospheric keywords. Frequency of the word occurrence is expressed by font size-the higher frequency the bigger font (in the figure shown as a number of hits for the selected keywords, e.g., 98 hits for permafrost or 28 hits for GLOF), and is not comparable between different word clouds. Different color tones are only used to increase readability, they do not refer to any variable. Only words appearing three or more times are shown in these word clouds. 
Some of the word clouds also indicate a geographical focus (see also Section 3.2.2). "Siachen" - the most popular word in the titles of videos found for the keyword glacier $(6.0 \%)$-refers to the location. Both Indian and Pakistan armies are shown operating on Siachen glacier in Karakoram (e.g., Watch-Pakistan army vs. Indian army in Siachen Glacier | Life in World's highest battleground Siachen uploaded by K Point). "Alaskan" appears among the repeated words for the keyword jokulhlaup while "Alaska" for glacier, "Nepal" for glacial lake outburst flood and "Siberian" and "Arctic" for the keyword permafrost.

\subsubsection{Music, Gaming, Sports Videos and Movies}

A total of 224 videos in the database (26.1\% of all) are classified as music videos. Music videos dominate the database for the keyword snow $(59.0 \%)$ and ice $(47.0 \%)$, and also have a considerable share (over $20 \%$ ) among the videos found for the keyword avalanche (30.0\%), blizzard $(26.0 \%)$ and cryosphere (23.0\%). Clearly, this is caused by some of the general cryospheric keywords being used as a part of the artists' names (e.g., American rapper Ice Cube), music bands (e.g., Northern Irish rock band Snow Patrol), music albums (Permafrost by German musician Thomas Köner, released in 1993) or songs (e.g., Snow (Hey Oh) by Red Hot Chili Peppers, released in 2006). These are, not surprisingly, also ranked among the top-viewed videos, including the top-viewed video in the database-Frozen: Let It Go Sing-along uploaded to the Disney UK channel—soundtrack from Frozen music comedy, with over 1.6 billion views (in February 2019).

Gaming videos (videos capturing gamers playing a game and/or giving advice on how to play a game being the most common) represent a total of 129 records in the database (15.0\%). Gaming videos are especially represented among the top-viewed videos of four cryospheric keywords-blizzard ( $45.0 \%$; the most frequently represented video type for this keyword), permafrost (33.0\%), cryosphere $(28.0 \%)$ and avalanche (16.0\%). The League of Legends (keyword permafrost), Grand Theft Auto V (avalanche), Fortnite (permafrost), Mighty No. 9 (cryosphere) and World of Warcraft (blizzard) gaming videos are among the most viewed and the most liked. We argue that such a pattern could be explained with permafrost being one of the character's skills in the League of Legends and a harvesting tool in the Battle Royale of Fortnite. The vehicle avalanche (mass accident) refers to the popular funny moment of Grand Theft Auto V, Cryosphere is a robot with water- and ice-based abilities in Mighty No. 9, and World of Warcraft was developed by the Blizzard Entertainment video game company.

Undoubtedly, all winter sports are associated with the cryosphere; nevertheless, only a limited amount of sports videos is found among the top-viewed videos containing the cryosphere keywords ( $\mathrm{n}=42 ; 4.9 \%$ of all). Sports videos are found for the keyword avalanche (share $14.0 \%)$, glacier $(10.0 \%)$, snow (6.0\%) and GLOFs (12.2\%). The top-viewed sports video Snow Sports Battle | Dude Perfect by Dude Perfect shows the winter basketball/snowballing and the most liked video Fabio Wibmer-Fabiolous Escape 2 by Fabio Wibmer captures the downhill bike ride over the snowy slopes of Saalbach, Austria. While the video by Dude Perfect has a rather entertaining character, the latter mentioned captures professional sport skills. The videos from the Megavalanche extreme downhill race taking place in Alpe d'Huez, France, are also quite popular. Sports videos for the keyword glacial lake outburst flood (GLOF) are those of incorrectly written golf practicing videos.

A total of 44 videos (5.1\%) are classified as movies (including separated scenes from movies, TV series, etc.). These are represented among the top-viewed videos for all the keywords with the exception of the cryosphere and glacial lake outburst floods. The most viewed videos of this type are learning videos for kids (e.g., the S3E2 The Toys Come to Life episode Ice Cream). Our database also includes selected parts from popular Ice Age movies. Videos classified as others ( $\mathrm{n}=110 ; 12.8 \%$ ) do have a content which does not clearly fit in any of the five other categories. These are represented among the top-viewed videos for all keywords and more frequently represented for the general keyword ice $(33.0 \%)$ and glacier $(27.0 \%)$. An example is the video How to Pronounce Cryosphere by Emma Saying or video PERMAFROST!! by Seigbiff. The latter mentioned has a length 0:00:06 and captures a guy 
from Abbath metal band screaming "permafrost". Surprisingly, this video published in 2009 has been viewed more than 100,000 times and is ranked the 37th most viewed video for the keyword permafrost.

\subsection{The Top-Viewed Videos with Cryospheric Content}

\subsubsection{The Most Popular Cryosphere Components and Phenomena}

The top-viewed video with cryospheric content is titled "CHASING ICE" captures largest glacier calving ever filmed-OFFICIAL VIDEO published by the Exposure Labs (see Table 2). This video has been played 55M times (in February 2019) and is the most viewed for keywords glacier and ice. In terms of views, the phenomenon of glacier calving has attracted the highest attention of the public YouTube audience, suggesting general interest in "eye-catching" dynamic cryosphere-related processes. This is also confirmed by the top-viewed snow videos where two out of three videos capture a train passing through a thick snow cover. The top-viewed videos found for the keyword permafrost are dominated by compilations of objects found in the degrading permafrost, e.g., mummified animal bodies, which are also a subject of scientific research (e.g., [43]). This is the case of the video Top 10 Mysterious Things Found Frozen In Ice Antarctica, which attracted the highest average number of views per day (55,308.7 views per day) among the videos published in 2018 or earlier. The top three videos for the keyword cryosphere were published by NASA (NASA and NASA Goddard channels), and these could be described as educational (see also Section 4.1). The attention attracted is, however, an order of magnitude that is lower compared to other general keywords.

Table 2. The top-viewed videos with cryospheric content. Three top-viewed videos (total views; in February 2019) are shown for each of the five general cryosphere keywords (only two videos with cryospheric content were found among 100 top-viewed videos for the keyword ice).

\begin{tabular}{|c|c|c|c|c|}
\hline Title & Author & Published & Views & Views Per Day \\
\hline \multicolumn{5}{|l|}{ Keyword: cryosphere } \\
\hline NASA | A Tour of the Cryosphere 2009 & $\begin{array}{l}\text { NASA } \\
\text { Goddard }\end{array}$ & 2009 & $172 \mathrm{k}$ & 49.9 \\
\hline NASA | A Short Tour of the Cryosphere & $\begin{array}{l}\text { NASA } \\
\text { Goddard }\end{array}$ & 2007 & $54 \mathrm{k}$ & 12.3 \\
\hline NASA Explorers: Cryosphere-The Big Thaw & NASA & 2018 & $27 \mathrm{k}$ & 254.7 \\
\hline \multicolumn{5}{|l|}{ Keyword: glacier } \\
\hline $\begin{array}{l}\text { "CHASING ICE" captures largest glacier calving ever } \\
\text { filmed-OFFICIAL VIDEO }\end{array}$ & Exposure Labs & 2012 & $55 \mathrm{M}$ & $24,641.6$ \\
\hline Glacier Calving, Huge Wave & rqmondo & 2010 & $6.8 \mathrm{M}$ & 2149.9 \\
\hline Glacier bridge collapses in Perito Moreno || Viral Video UK & ViralVideoUK & 2016 & $6.6 \mathrm{M}$ & 6451.6 \\
\hline \multicolumn{5}{|l|}{ Keyword: ice } \\
\hline $\begin{array}{l}\text { “CHASING ICE” captures largest glacier calving ever } \\
\text { filmed-OFFICIAL VIDEO }\end{array}$ & Exposure Labs & 2012 & $55 \mathrm{M}$ & $24,641.6$ \\
\hline Top 10 Mysterious Things Found Frozen In Ice Antarctica & Top-5 Top-10 & 2017 & $25 \mathrm{M}$ & $55,309.7$ \\
\hline \multicolumn{5}{|l|}{ Keyword: permafrost } \\
\hline Los 5 Hallazgos bajo el Hielo mas Increíbles de la Historia & EnigmaCinco & 2016 & $3.7 \mathrm{M}$ & 3843.2 \\
\hline 14 Most Amazing Permafrost Discoveries from Siberia & Extinction Blog & 2017 & $1.0 \mathrm{M}$ & 2421.3 \\
\hline The Permafrost Mystery: scientists explore giant Yamal Sinkhole & $\begin{array}{c}\text { RT } \\
\text { Documentary }\end{array}$ & 2015 & $950 \mathrm{k}$ & 787.1 \\
\hline \multicolumn{5}{|l|}{ Keyword: snow } \\
\hline \multirow{3}{*}{$\begin{array}{c}\text { Amtrak Snow-mo Collision } \\
\text { Frozen Fails | An Epic Snow and Ice Fail Compilation by FailArmy } \\
\text { EPIC CATCH!!! Dashing Thru the Snow-CN Train } 406 \text { West at } \\
\text { Salisbury, NB }\end{array}$} & Nick Colvin & 2017 & $17 \mathrm{M}$ & $24,602.0$ \\
\hline & FailArmy & 2015 & $15 \mathrm{M}$ & $10,259.9$ \\
\hline & containerman2 & 2015 & $14 \mathrm{M}$ & 9575.9 \\
\hline
\end{tabular}

Similarly to the views and views per day, the most popular videos in terms of obtained likes vary in order of magnitude among the keywords as well as within individual keywords. Six videos with the cryospheric content reached over 100,000 likes, of which two were for keywords avalanche and snow and one for keywords blizzard and ice (see Table 3). The most liked video with cryospheric content is Solo Overnight Camping In Blizzard-70 Subscriber Special by Nickolas Green Outdoors, which got more 
than 250,000 likes. This video is, at the same time, the most viewed video for the keyword blizzard (see Section 3.3.1). The total of likes, however, corresponds with the number of subscribers of the author; five out of ten top liked videos were published by the authors with over 5,000,000 subscribers. An exception is the third most liked video Amtrak Snow-mo Collision (132,000 likes) by Nick Colvin, who has only 11,000 subscribers. Surprisingly, the general and specific cryospheric keywords are represented equally among the top-liked videos, despite the fact that videos of specific keywords do have considerably lower views. Only three out of 14 top-viewed videos listed for general keywords (see Table 2) are among the 10 top-liked videos, which does not suggest a simple relationship between views and likes.

Table 3. The most liked videos with factual cryospheric content (in February2019).

\begin{tabular}{|c|c|c|c|c|c|}
\hline Title & Author & Subscribers & Published & Likes & Keyword \\
\hline Solo Overnight Camping In Blizzard—70 Subscriber Special & $\begin{array}{l}\text { Nickolas Green } \\
\text { Outdoors }\end{array}$ & $282 \mathrm{k}$ & 2018 & $253 \mathrm{k}$ & blizzard \\
\hline WE ESCAPED AN AVALANCHE! (Raw Footage) & $\begin{array}{l}\text { Logan Paul } \\
\text { Vlogs }\end{array}$ & $18 \mathrm{M}$ & 2017 & $191 \mathrm{k}$ & avalanche \\
\hline Amtrak Snow-mo Collision & Nick Colvin & $11 \mathrm{k}$ & 2017 & $132 \mathrm{k}$ & snow \\
\hline Top 10 Mysterious Things Found Frozen In Ice Antarctica & Top-5 Top-10 & $180 \mathrm{k}$ & 2017 & $131 \mathrm{k}$ & ice \\
\hline $\begin{array}{c}\text { He Spent } 40 \text { Years Alone in the Woods, and Now Scientists Love } \\
\text { Him | Short Film Showcase }\end{array}$ & $\begin{array}{l}\text { National } \\
\text { Geographic }\end{array}$ & $10 \mathrm{M}$ & 2017 & $119 \mathrm{k}$ & snow \\
\hline Frozen Fails | An Epic Snow and Ice Fail Compilation by FailArmy & FailArmy & $14 \mathrm{M}$ & 2015 & $96 \mathrm{k}$ & snow \\
\hline $\begin{array}{l}\text { “CHASING ICE” captures largest glacier calving ever } \\
\text { filmed-OFFICIAL VIDEO }\end{array}$ & Exposure Labs & $13 \mathrm{k}$ & 2012 & $71 \mathrm{k}$ & glacier, ice \\
\hline Beautiful 48 h Time-Lapse of 2016 Blizzard & WorseThanChiggers & $14 \mathrm{k}$ & 2016 & $70 \mathrm{k}$ & blizzard \\
\hline NYC BLizzard FAILURE & CaseyNeistat & $10 \mathrm{M}$ & 2017 & $62 \mathrm{k}$ & blizzard \\
\hline
\end{tabular}

\subsubsection{Geographical Distribution}

The geographical location has been assigned to 192 out of 310 videos $(61.9 \%)$ with factual cryospheric content. Figure 3 shows that videos with cryospheric content were filmed in all the world's continents except for Africa. It also reveals several hotspots of which Alaska $(n=60 ; 31.3 \%$ of all with geographic focus; $19.4 \%$ of all with factual cryospheric content, respectively), Iceland ( $n=20 ; 10.2 \%$; 6.5\% respectively) and Central Asia (Hindu Kush-Himalaya-Karakoram-Tibet region; $n=29 ; 15.1 \%$; 9.3\% respectively) dominate. Videos of individual cryosphere keywords are distributed unevenly all over the globe; while jokulhlaups dominate in the Alaska hotspot, GLOFs dominate in Central Asia, avalanche in European Alps, the Caucasus and Pacific Northwest, permafrost in Siberia, Tibet and Northern Canada and blizzard on the East coast of the USA. Glacier dominates in Antarctica, Patagonia and Greenland.

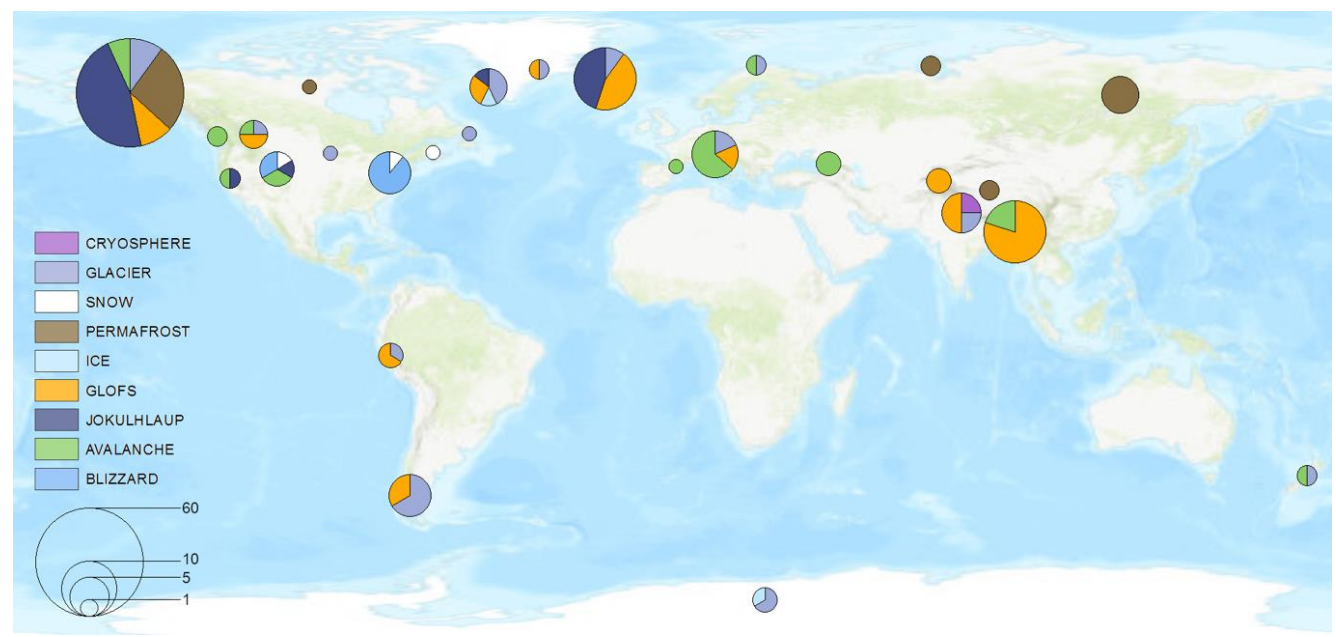

Figure 3. Location of videos with factual cryospheric content. Note differences in the presence and the share of individual keywords among the regions. 


\subsection{The Top-Viewed Videos about Cryospheric Hazards}

\subsubsection{Avalanche and Blizzard}

Actual avalanche content was captured on 35 videos out of the 100 most viewed ones. Almost all videos show ongoing avalanche events. The top-viewed video Hit by Avalanche in Everest Basecamp 25.04.2015 by Jost kobusch captured a disastrous M7.8 Gorkha earthquake-induced avalanche in Nepal (see [44,45]; see Figure 4A). Climber Jost Kobusch who filmed the video of the disaster managed to escape and survived but at least 18 people died on Everest during this event. The most liked video WE ESCAPED AN AVALANCHE! (Raw Footage) by Logan Paul Vlogs captures the trip to the Giant Forest of the Sequoia National Park in California. Only a small avalanche is captured in the video, hence the title sounds much more dramatic than it actually is, perhaps resulting in the high amount of received likes. Beyond naturally triggered avalanches, several videos show artificially triggered avalanches caused by skiers or by shooting from artillery guns by Russian soldiers.

The keyword blizzard returned 16 videos with actual cryospheric content out of the 100 most viewed. The top-viewed video Solo Overnight Camping In Blizzard-70 Subscriber Special by Nickolas Green Outdoors is the most liked video at the same time. A very young YouTuber-after reaching 70 subscribers-decided to spend a night alone in very cold weather. There are several videos about camping during a blizzard, indicating the interest of viewers in seemingly extreme actions. Notwithstanding, videos capturing blizzard events, which take place in towns predominate our database (see Figure 4B).

\subsubsection{Glacial Lake Outburst Floods (GLOFs) and Jokulhlaups}

The search for the keyword glacial lake outburst flood returned 98 results and jokulhlaup returned 61 results, of which $123(78.6 \%)$ are classified as videos with factual cryospheric content. Some of these videos do capture lake outbursts, while others capture their consequences. The top-viewed video Russell Glacier Lake bursts by WOGACGreenland shows calving of the Russell Glacier (West Greenland; see also [46]) into the adjacent proglacial lake/meltwater river, producing a displacement wave running towards the cameraman's position (see Figure 4C). The most liked video The Most Dangerous Lake in Nepal by Daniel Byers is a clip about the GLOF-susceptible Lake 464 from the planned movie Outburst. This particular lake has also been a subject of a scientific study by Byers et al. [47]. Due to the stochastic occurrence of GLOFs in space and time and the frequent location of outburst flood-producing lakes in remote mountain areas, lakes are rarely captured during the outburst.

As such, YouTube videos have the potential to shed light on causes and mechanisms of GLOFs (see Section 4.1.2). In our database, a rare example is the time series video capturing the outburst of the well-studied (see [48]) Bear glacier ice-dammed lake in August 2018, published by Kenai Fjords NPS (see Figure 4D). Jökulhlaups in a strict generic sense (i.e., a flood following the volcanic activity-induced rapid melting of glacier ice; [49]) are captured on a very limited amount of videos, e.g., Eyjafjallajökull jökulhlaup on 14 April 2010, Iceland (see Figure 4E). More frequently, the flood propagation further downstream is documented (Figure $4 \mathrm{~F}$ ). However, it is complicated to distinguish whether these are actually caused by lake outbursts or not. 


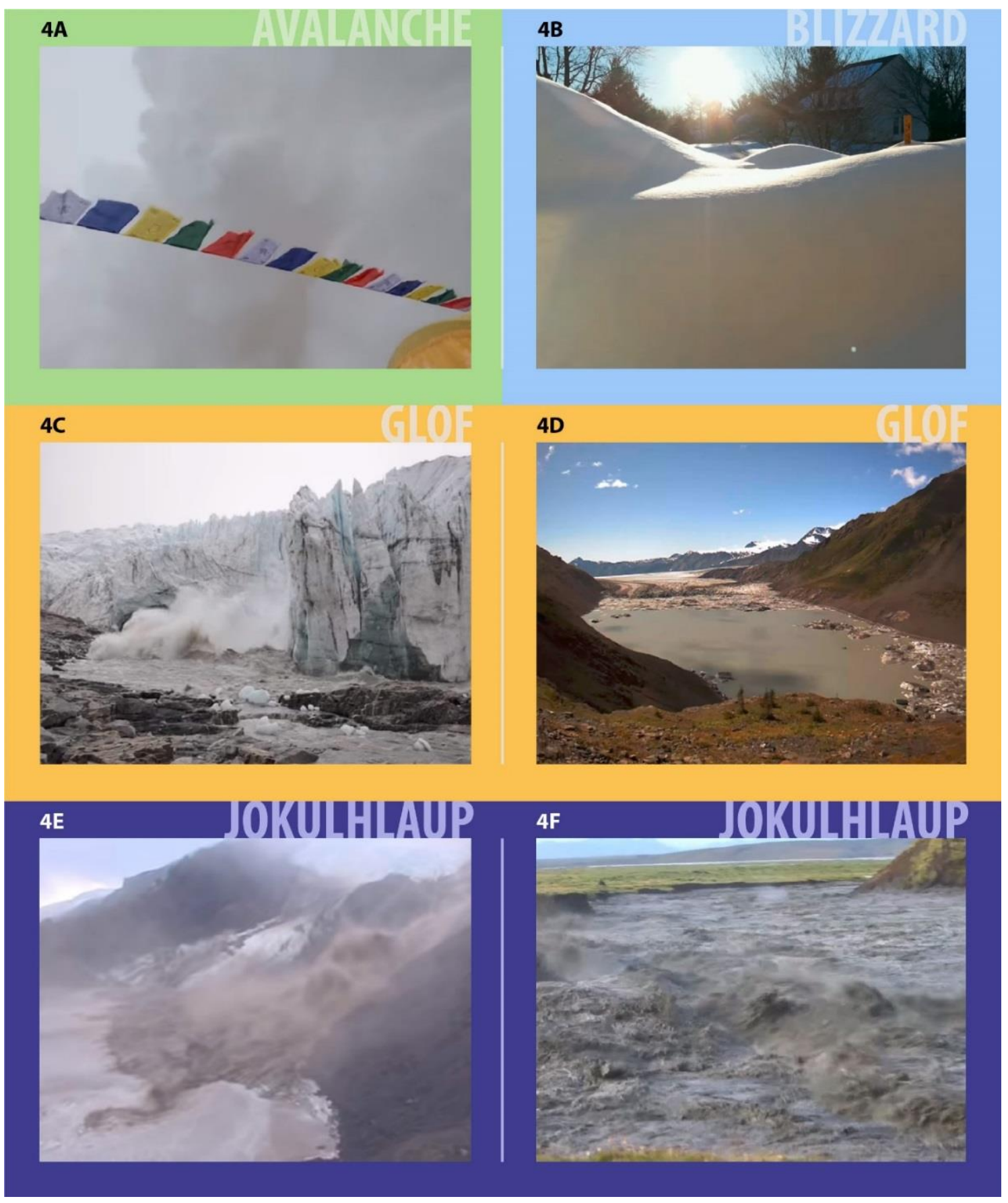

Figure 4. Printscreens from videos capturing selected types of cryospheric hazards. Part (A) shows the avalanche cloud just a few seconds before hitting the Everest basecamp on 25 April 2015 (Hit by Avalanche in Everest Basecamp 25.04.2015 by Jost kobusch); part (B) shows about $1 \mathrm{~m}$ of new snow resulting from a blizzard in the Northern Virginia, 22-24 January 2016 (Beautiful $48 \mathrm{~h}$ Time-Lapse of 2016 Blizzard uploaded by WorseThanChiggers); part (C) shows the water displacement following the glacier calving into the adjacent proglacial lake/meltwater river at Russell Glacier, West Greenland (Source: Russell Glacier Lake bursts by WOGACGreenland); part (D) shows the pre-outburst state of the lake at Bear Glacier, Alaska, on 9 August 2018, taken from the time-lapse camera (Source: Bear Glacier Ice-dammed Lake Outburst Flood, August 2018 by Kenai Fjords NPS); part (E) shows Eyjafjallajökull jokulhlaup on 14 April 2010, Iceland (Source: Eyjafjallajökull glacial flood (jökulhlaup) 14 April 2010 by hpjons); and part (F) shows previously unreported 2015 Skaftárhlaup jokulhlaup on Iceland (Source: Skaftárhlaup_3_BDMV by Pall Jokull Petursson). 


\section{Discussion and Outlook}

\subsection{Potential of YouTube Videos for Educational and Research Purposes}

General potentials and limitations of YouTube videos are outlined in Section 1. In this section, the potential of YouTube cryosphere videos for educational (see Section 4.1.1) and research purposes (see Section 4.1.2) are discussed.

\subsubsection{Educational Purposes}

Being accessible to and accessed by billions of users, YouTube.com has the power and potential to communicate content to a broad public audience and thus has a cognitive value as an educational content [50]. While YouTube has been recognized as an emerging source of information and an educational tool across various disciplines of science (e.g., [51-53]), recently also including the field of physical geography [54], it is also necessary to take the reliability of the content in the virtual space into an account (see the example of Twitter [55]). The content uploaded to YouTube can intentionally or unintentionally contain incomplete, misleading, tendentious or even incorrect information. This is a general feature of the current "freedom-of-speech" online environment. However, recent efforts of Google (the owner of YouTube) try to address this issue with the plan of providing short descriptions offering essential science-based information [56]. Such information would be linked to longer explanations on Wikipedia to help fighting with disinformation. Global warming-a key issue in cryosphere science-is among the themes included in this programme (other is the measles, mumps and rubella vaccine). According to Brainard [56], automatically identified videos paddling climate misinformation are accompained by the message "Multiple lines of scientific evidence show that the climate system is warming".

While YouTube offers a broad range of sorting (by views, by relevance, by rating, by upload date) and filtering (duration, features, type) among the results found, no specific setting is available to sort out the educational videos. For educational purposes, we thus recommend searching among the institutional channels of research/professional organizations. However, there are also certainly useful personal channels of which we also provide examples in this section.

Among the authors of the videos in our database, several educational channels/channels focusing on dissemination of scientific results are represented. Among these, NASA and NASA Goddard institutional channels attract the highest attention in terms of views (see also Table 1). Other examples are produced by the ICIMOD (International Centre for Integrated Mountain Development), e.g., the video Climate Change and its Impacts on Cryosphere and Water Resources of the HKH, or by the University of California Irvine (Earth System Science 1: Intro to ESS. Lecture 16. Cryosphere).

One of the few personal channels focusing on the systematic education in cryosphere science is a channel of Simon Clark-video maker and science communicator from Bristol, UK, who gained his $\mathrm{PhD}$ at the University of Exeter. Each episode of his series Crash Course Cryosphere attracted thousands of views. These numbers are comparable to the attention attracted by the videos published by institutional channels of large research organizations. Another example of videos with educational cryosphere content is a talk by Dr Richard S. Williams (Geoscience Information Services) on the topic The Earth's Disappearing Cryosphere: Glaciers, Snow Cover, Floating Ice, and Permafrost.

Apart from communicating and disseminating scientific results to the broader public audience, Goudie [57] in his work on aesthetic and relevance in outreach pointed out that the aesthetic is essential for making geomorphology a discipline that appeals to the general public and to potential students-this can also be adopted for the cryosphere science. Appropriately made videos published at YouTube certainly have the potential to do a good job in this regard.

\subsubsection{Research Purposes}

Besides YouTube being a powerful method of outreach and a useful tool for knowledge dissemination and communication [58], geosciences can benefit from online videos as the material 
uploaded by public users potentially contains a great amount of worthwhile data. For instance, natural hazards of mass movements such as landslides, rockfalls or GLOFs are difficult to record as they often happen unexpectedly and in remote areas, e.g., high mountains [54]. More specifically, these videos have the potential to contribute to the elucidation of dynamics, magnitude and behavior of different types of mass movements originating within the cryospheric environment. Witnesses of these events commonly shoot videos which are uploaded to online platforms afterwards [59]. Rare events are thus recorded by citizens rather than researchers and science can benefit from the large data repository which would otherwise be unavailable [35,54]. Lewis and Park [54] documented that contemporary advanced technological capability enabled the enhanced processing and analyzing of these audiovisual materials. As an example, these volunteered geographic videos were used for the extraction of the topographical data in the area affected by a landslide and also employed to study extreme floods. Such a trend is also observed among the videos in our database, where a considerable part of videos with cryospheric content has been uploaded by users with personal channels (not institutional channels such as the one of NASA).

Especially in case of GLOFs, comprehensive databases of previous events are of the utmost importance in efforts to understand the patterns of their occurrence in space and time [60]. In this particular case, videos of such events taken by incidental witnesses have the potential to contribute to these efforts, if shared. An example of previously unreported GLOF (here we refer to Carrivick and Tweed global inventory of GLOFs [61]) found among the YouTube videos is Skaftárhlaup_3_BDMV by Pall Jokull Petursson capturing a flood in 2 October 2015, Iceland (see Figure 4D). In addition, such videos can provide insights into the erosion-transport-accumulation interactions (e.g., the amount and size of transported boulders) and could be also used to estimate the maximum flood height and flow speed, for instance [54]. Such information is desirable to back-calculate these extreme events and set up the parameters of the model used [62]. However, some problems remain regarding the validation and determination of the location where the video has been filmed, if not explicitly indicated.

\subsection{The Relationship between Views, Likes, Dislikes and Subscribers}

In this study, we assume that the more viewed/liked videos reflect a higher interest of the broader public audience. However, one could argue that the total of views and likes is rather driven by the total subscriptions, expecting that the video published by the author with a high amount of subscribers will receive more views and likes respectively. In this section, we reveal the relationship between these characteristics. Our data suggest that the relationship between the total number of subscribers and other characteristics is rather weak, with $R^{2}$ ranging from 0.36 to 0.42 for the entire dataset and 0.18 to 0.29 for the subset of the videos with factual cryospheric content (see Figure $5 \mathrm{~A}-\mathrm{C}$ ). We also show that the total of views is closely tied with likes and dislikes, with $R^{2}$ ranging from 0.73 to 0.89 for the entire dataset and 0.83 to 0.89 for the subset of the videos with factual cryospheric content (see Figure 5C-E). Using the analogy to the study of Tahamatan et al. [63], we opine that the total of views is rather controlled by other qualitative characteristics of the video, such as the catchiness of the title, quality and interest of the content or other factors influencing virality [64]. Thus, we argue that the total of views and likes can be used as an indicator of the interest of the public audience in a given subject-different components of the cryosphere in our case.

\subsection{Outlook}

Containing a huge amount of audiovisual materials, YouTube has been recognized as a valuable source of information across scientific disciplines. At the same time, YouTube represents a powerful communication tool for outreach and dissemination of science. Our study provides the first insights into the top-viewed videos found for nine cryospheric keywords, covering essential components of the cryosphere and selected cryospheric hazards. We explore the most viewed and the most liked videos with factual cryospheric content, showing the interest of the public audience, especially in rapid/dynamic processes and mysterious phenomena, and we show that personal channels may attract 
higher attention (views, likes, subscribers) compared to the official institutional channels. Our analysis corroborates previous claims that the content stored at YouTube can serve for both educational and research purposes, here supported by concrete examples from the cryospheric science. While our dataset only reveals a limited amount of videos available at YouTube for some of the specific keywords (e.g., GLOFs), we opine that the expected increasing of future availability of connectable devices and internet access will further strengthen the connections between the social media and cryospheric science, both for outreach and data mining.

(A)

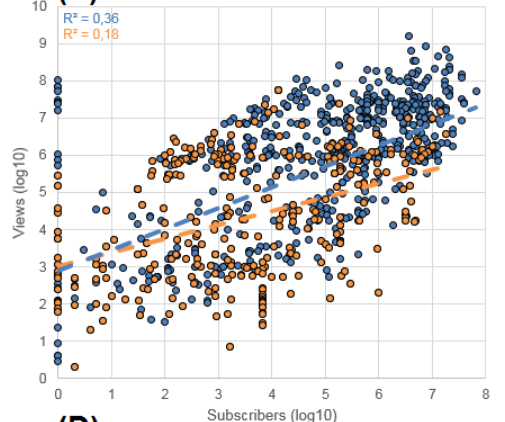

(D)

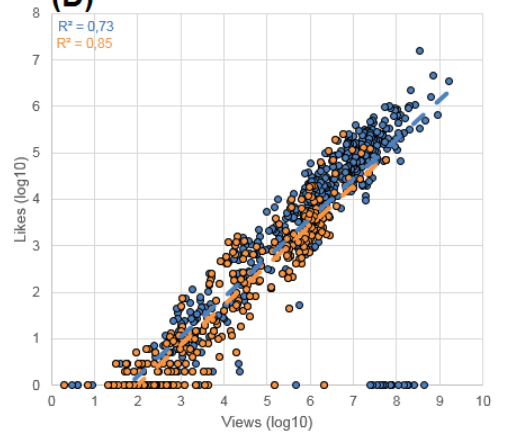

(B)

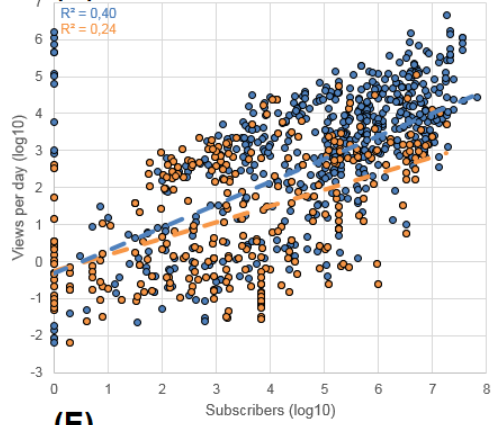

${ }_{6}(\mathrm{E})$

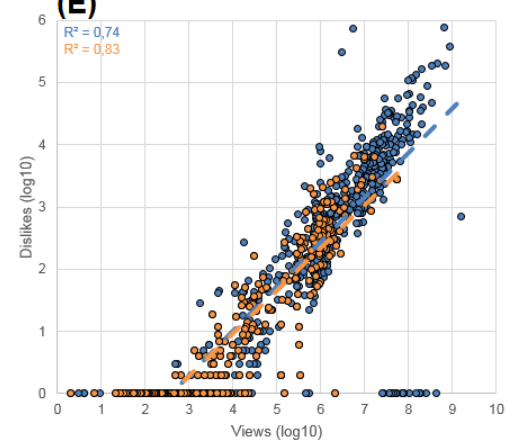

(C)

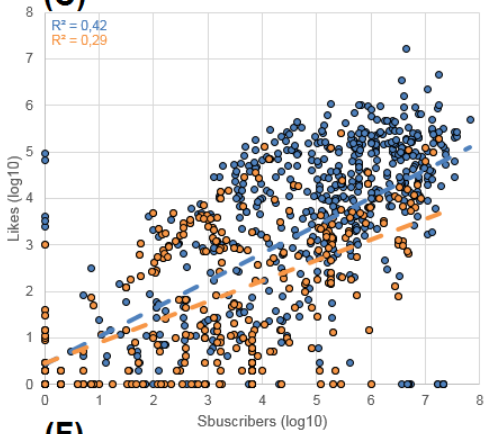

(F)

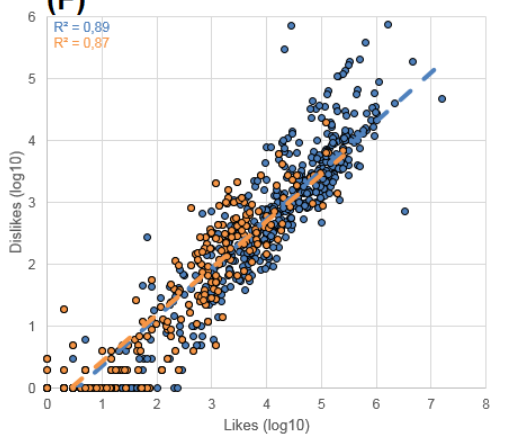

Figure 5. The relationship between the total number of subscribers, views, views per day, likes and dislikes. Data for the whole dataset are colored in blue while data for the subset of videos with factual cryospheric content are colored in orange.

Supplementary Materials: The following are available online at http://www.mdpi.com/2076-3263/9/4/181/s1.

Author Contributions: A.E. designed the study, analyzed data and interpreted obtained results. P.K. contributed to the database building and data analysis. V.C. analyzed the geographical focus of videos with cryospheric content and created the map. H.D. reviewed the literature on the use of YouTube in scientific studies. J.D. conducted the word cloud analysis, designed and prepared figures. All authors discussed the content, contributed to the writing process and approved the final version of the manuscript.

Funding: This work was supported by the Ministry of Education, Youth and Sports of the Czech Republic within the National Sustainability Programme I (NPU I), grant number LO1415. J.D. acknowledges support from the Specific Academic Research project "Research on social and environmental innovations", grant number vs. 260471.

Acknowledgments: We thank two anonymous reviewers for their insightful comments and suggestions.

Conflicts of Interest: The authors declare no conflict of interest.

\section{References}

1. Intergovernmental Panel on Climate Change (IPCC). Contribution of Working Group I to the Fifth Assessment Report of the Intergovernmental Panel on Climate Change; Cambridge University Press: Cambridge, UK; New York, NY, USA, 2013; 1522p.

2. Huss, M.; Bookhagen, B.; Huggel, C.; Jacobsen, D.; Bradley, R.S.; Clague, J.J.; Vuille, M.; Buytaert, W.; Cayan, D.R.; Greenwood, G.; et al. Toward mountains without permanent snow and ice. Earths Future 2017, 5, 418-435. [CrossRef] 
3. Rogelj, J.; den Elzen, M.; Hohne, N.; Fransen, T.; Fekete, H.; Winkler, H.; Chaeffer, R.S.; Ha, F.; Riahl, K.; Meinshausen, M. Paris Agreement climate proposals need a boost to keep warming well below 2 degrees $C$. Nature 2015, 534, 631-639. [CrossRef] [PubMed]

4. Roe, G.H.; Baker, M.B.; Herla, F. Centennial glacier retreat as categorical evidence of regional climate change. Nat. Geosci. 2017, 10, 95. [CrossRef]

5. Screen, J.A. Cryosphere Arctic sea ice at 1.5 and 2 degrees C. Nat. Clim. Chang. 2018, 8, 362-363. [CrossRef]

6. Garavaglia, V.; Diolaluti, G.; Smiraglia, C.; Pasquale, V.; Pelfini, M. Evaluating tourist perception of environmental changes as a contribution to managing natural resources in glacierized areas: A case study of the forni glacier (Stelvio National Park, Italian Alps). Environ. Manag. 2012, 50, 1125-1138. [CrossRef] [PubMed]

7. Deng, M.Z.; Qin, D.H.; Zhang, H.G. Public perceptions of climate and cryosphere change in typical arid inland river areas of China: Facts, impacts and selections of adaptation measures. Quat. Int. 2012, 282, 48-57. [CrossRef]

8. Xiao, C.-D.; Wang, S.J.; Qin, D.H. A preliminary study of cryosphere service function and value evaluation. Adv. Clim. Chang. Res. 2015, 6, 181-187. [CrossRef]

9. Demiroglu, O.C.; Dannevig, H.; Aall, C. Climate change acknowledgement and responses of summer (glacier) ski visitors in Norway. Scand. J. Hosp. Tour. 2018, 18, 419-438. [CrossRef]

10. Chaudhary, P.; Rai, S.; Wangdi, S.; Mao, A.; Rehman, N.; Chettri, S.; Bawa, K.S. Consistency of local perceptions of climate change in the Kangchenjunga Himalaya landscape. Curr. Sci. 2011, 101, 504-513.

11. Anderegg, W.R.L.; Goldsmith, G.R. Public interest in climate change over the past decade and the effects of the 'climategate' media event. Environ. Res. Lett. 2014, 9, 054005. [CrossRef]

12. Gioli, G.; Khan, T.; Scheffran, J. Climatic and environmental change in the Karakoram: Making sense of community perceptions and adaptation strategies. Reg. Environ. Chang. 2014, 14, 1151-1162. [CrossRef]

13. Bury, J.T.; Mark, B.G.; McKenzie, J.M.; French, A.; Baraer, M.; Huh, K.I.; Luyo, M.A.Z.; Lopez, R.J.G. Glacier recession and human vulnerability in the Yanamarey watershed of the Cordillera Blanca, Peru. Clim. Chang. 2011, 105, 179-206. [CrossRef]

14. Jurt, C.; Burga, M.D.; Vicuna, L.; Huggel, C.; Orlove, B. Local perceptions in climate change debates: Insights from case studies in the Alps and the Andes. Clim. Chang. 2015, 133, 511-523. [CrossRef]

15. Vuille, M.; Carey, M.; Huggel, C.; Buytaert, W.; Rabatel, A.; Jacobsen, D.; Soruco, A.; Villacis, M.; Yarleque, C.; Elison Timm, O.; et al. Rapid decline of snow and ice in the tropical Andes-impacts, uncertainties and challenges ahead. Earth Sci. Rev. 2018, 176, 195-213. [CrossRef]

16. Gagne, K.; Rasmussen, M.B.; Orlove, B. Glaciers and society: Attributions, perceptions, and valuations. Wiley Interdiscip. Rev. Clim. Chang. 2014, 5, 793-808. [CrossRef]

17. Allison, E.A. The spiritual significance of glaciers in an age of climate change. Wiley Interdiscip. Rev. Clim. Chang. 2015, 6, 493-508. [CrossRef]

18. Scoville-Simonds, M. Climate, the earth, and god-Entangled narratives of cultural and climatic change in the Peruvian Andes. World Dev. 2018, 110, 345-359. [CrossRef]

19. Buytaert, W.; Zulkafli, Z.; Grainger, S.; Acosta, L.; Alemie, T.C.; Bastiaensen, J.; De Bièvre, B.; Bhusal, J.; Clark, J.; Dewulf, A.; et al. Citizen science in hydrology and water resources: Service management and suitable development. Frontiers Earth Sci. 2014, 2, 26. [CrossRef]

20. Schnebele, E.; Cervone, G. Improving remote sensing flood assessment using volunteered geographical data. Nat. Hazards Earth Syst. Sci. 2013, 12, 669-677. [CrossRef]

21. Newman, G.; Wiggins, A.; Crall, A.; Graham, E.; Newman, S.; Crowston, K. The future of citizen science: Emerging technologies and shifting paradigm. Front. Ecol. Environ. 2012, 10, 298-304. [CrossRef]

22. Pasquali, M. Video in science. Protocol videos: The implications for research and society. EMBO Rep. 2007, 8, 712-716. [CrossRef]

23. Clarivate Analytics Web of Science. Available online: www.webofknowledge.com (accessed on 27 March 2019).

24. Duncan, I.; Yarwood-Ross, L.; Haigh, C. YouTube as a source of clinical skills education. Nurse Educ. Today 2013, 33, 1576-1580. [CrossRef] [PubMed]

25. Eusden, J.D.; Duval, M.; Bryant, M. Google earth mashup of the geology in the presidential range, New Hampshire: Linking real and virtual fieldtrips for an introductory geology class. Geol. Soc. Am. 2012, 492, 355-366. 
26. Elwood, S.; Goodchild, M.F.; Sui, D.Z. Researching volunteered geographic information: Spatial data, geographic research, and new social practice. Ann. Assoc. Am. Geogr. 2012, 102, 571-590. [CrossRef]

27. Assumpção, T.H.; Popescu, I.; Jonoski, A.; Solomatine, P. Citizen observations contributing to flood modelling: Opportunities and challenges. Hydrol. Earth Syst. Sci. 2018, 22, 1473-1489. [CrossRef]

28. Goodchild, M.F. Citizens as sensors: The world of volunteered geography. GeoJournal 2007, 69, $211-221$. [CrossRef]

29. Kobori, H.; Dickson, J.L.; Washitani, I.; Sakurai, E.; Amano, T.; Komatsu, N.; Kitamura, W.; Takagawa, S.; Kozoma, K.; Ogawara, T.; et al. Citizen science: A new approach to advance ecology, education, and conservation. Ecol. Res. 2016, 31, 1-19. [CrossRef]

30. El Bizri, H.R.; Mocatty, T.Q.; Lima, J.J.S.; Valsecchi, H. The trill of the chase: Uncovering illegal sport hunting in Brazil through YouTube ${ }^{\mathrm{TM}}$ posts. Ecol. Soc. 2015, 20, 30. [CrossRef]

31. Silvertown, J. A new dawn for citizen science. Trends Ecol. Evol. 2009, 24, 467-471. [CrossRef]

32. Tang, Z.; Zhang, L.; Xu, F.; Vo, H. Examining the role of social media in California's draught risk management in 2014. Nat. Hazards 2015, 79, 171-193. [CrossRef]

33. Amato, A.; Arcoraci, L.; Casarotti, E.; Di Stefano, R. The INGVterremoti channel on YouTube. Ann. Geophys. 2012, 55, 403-408.

34. Lang, N.P.; Land, K.T.; Camodeca, B.M. A geology-focused virtual fieldtrip to Tenerife, Spain. Geol. Soc. Am. 2012, 492, 323-334.

35. Klonner, C.; Marx, S.; Usón, T.; de Albuquerque, J.P.; Höfle, B. Volunteered geographic information in natural hazard analysis: A systematic literature review of current approaches with a Focus on preparedness and mitigation. ISPRS Int. J. Geo Inf. 2016, 5, 103. [CrossRef]

36. Heipke, C. Crowdsourcing geospatial data. ISPRS J. Photogramm. Remote Sens. 2010, 65, 550-557. [CrossRef]

37. MDPI. Special Issue Cryosphere II; MDPI: Basel, Switzerland, 2018; p. 1.

38. Emmer, A. Geographies and scientometrics of research on natural hazards. Geosciences 2018, 8, 382. [CrossRef]

39. MAXQDA 2018.2. Professional Software for Qualitative \& Mixed Methods Research. The Art of Data Analysis. Available online: www.maxqda.com (accessed on 27 March 2019).

40. McGee, R.G.; Craig, J.C. What is being published? A word cloud of titles from the journal of paediatrics and child health. J. Paediatr. Child Health 2012, 48, 452. [CrossRef]

41. Li, D.Y.; Zhou, X.L. "Leave your footprints in my words"-A georeferenced word-cloud approach. Environ. Plan. A 2017, 49, 489-492. [CrossRef]

42. Atenstaedt, R. Word cloud analysis of the BJGP: 5 years on. Br. J. Gen. Pract. 2017, 67, 231-232. [CrossRef]

43. Schwarz, C.; Debruyne, R.; Kuch, M.; McNally, E.; Schwarcz, H.; Aubrey, A.D.; Bada, J.; Polnar, H. New insights from old bones: DNA preservation and degradation in permafrost preserved mammoth remains. Nucleic Acids Res. 2009, 37, 3215-3229. [CrossRef]

44. Goda, G.; Pokhrel, R.M.; Katagiri, T.; Chiaro, G.; Kiyota, T.; Sharma, K.; Wilkinson, S. The 2015 gorkha Nepal earthquake: Insights from earthquake damage survey. Front. Built Environ. 2015, 1, 8. [CrossRef]

45. Kargel, J.S.; Leonard, G.J.; Shugar, D.H.; Haritashya, U.K.; Bevington, A.; Fielding, E.J.; Fujita, K.; Geertsema, M.; Miles, E.S.; Steiner, J.; et al. Geomorphic and geologic controls of geohazards induced by Nepal's 2015 Gorkha earthquake. Science 2016, 351, aac8353. [CrossRef]

46. Carrivick, J.L.; Turner, A.G.D.; Russell, A.J.; Ingeman-Nielsen, T.; Yde, J.C. Outburst flood evolution at Russell Glacier, western Greenland: Effects of a bedrock channel cascade with intermediary lakes. Quat. Sci. Rev. 2013, 67, 39-58. [CrossRef]

47. Byers, A.C.; McKinney, D.C.; Somos-Valenzuela, M.; Watanabe, T.; Lamsal, D. Glacial lakes of the Hinku and Hongu valleys, Makalu Barun National Park and Buffer Zone, Nepal. Nat. Hazards 2013, 69, 115-139. [CrossRef]

48. Wilcox, A.C.; Wade, A.A.; Evans, E.G. Drainage events from a glacier-dammed lake, Bear Glacier, Alaska: Remote sensing and field observations. Geomorphology 2014, 220, 41-49. [CrossRef]

49. Emmer, A. GLOFs in the WOS: Bibliometrics, geographies and global trends of research on glacial lake outburst floods (Web of Science, 1979-2016). Nat. Hazards Earth Syst. Sci. 2018, 18, 813-827. [CrossRef]

50. Shoufan, A. Estimating the cognitive value of YouTube's educational videos: A learning analytics approach. Comput. Hum. Behav. 2019, 92, 450-458. [CrossRef]

51. Keelan, J.; Pavri-Garcia, V.; Tomlinson, G.; Wilson, K. YouTube as a source of information on immunization: A content analysis. JAMA J. Am. Med. Assoc. 2007, 298, 2482-2484. [CrossRef] 
52. Steinberg, P.L.; Wason, S.; Stern, J.M.; Deters, L.; Kowal, B.; Seigne, J. YouTube as source of prostate cancer information. Urology 2010, 75, 619-622. [CrossRef]

53. Jaffar, A.A. YouTube: An emerging tool in anatomy education. Anat. Sci. Educ. 2012, 5, 158-164. [CrossRef]

54. Lewis, Q.W.; Park, E. Volunteered geographic videos in physical geography: Data mining from YouTube. Ann. Am. Assoc. Geogr. 2018, 108, 52-70. [CrossRef]

55. Vosoughi, S.; Roy, D.; Aral, S. The spread of true and false news online. Science 2018, 359, 1146. [CrossRef]

56. Brainard, J. YouTube clarifies science videos. Science 2018, 361, 629.

57. Goudie, A.S. Aesthetics and relevance in geomorphological outreach. Geomorphology 2002, 47, $245-249$. [CrossRef]

58. Krajewski, J.M.T.; Schumacher, A.C.; Dalrymple, K.E. Just turn on the faucet: A content analysis of PSAs about the global water crisis on YouTube. Environ. Commun. 2019, 13, 255-275. [CrossRef]

59. Le Boursicaud, R.; Pénard, L.; Hauet, A.; Thollet, F.; Le Coz, J. Gauging extreme floods on YouTube: Application of LSPIV to home movies for the post-event determination of stream discharges. Hydrol. Process. 2015, 30, 90-105. [CrossRef]

60. Emmer, A.; Vilímek, V.; Huggel, C.; Klimeš, J.; Schaub, Y. Limits and challenges to compiling and developing a database of glacial lake outburst floods. Landslides 2016, 16, 1579-1584. [CrossRef]

61. Carrivick, J.L.; Tweed, F.S. A global assessment of the societal impacts of glacier outburst floods. Glob. Planet. Chang. 2016, 144, 1-16. [CrossRef]

62. Mergili, M.; Emmer, A.; Juřicová, A.; Cochachin, A.; Fischer, J.-T.; Huggel, C.; Pudasaini, S.P. How well can we simulate complex hydro-geomorphic process chains? The 2012 multi-lake outburst flood in the Santa Cruz Valley (Cordillera Blanca, Perú). Earth Surf. Process. Landf. 2018, 43, 1373-1389. [CrossRef]

63. Tahamatan, I.; Afshar, A.S.; Ahamdzadekh, K. Factors affecting number of citations: A comprehensive review of the literature. Scientometrics 2016, 107, 1195-1225. [CrossRef]

64. Khan, G.F.; Vong, S. Virality over YouTube: An empirical analysis. Internet Res. 2014, 24, 629-647. [CrossRef]

(C) 2019 by the authors. Licensee MDPI, Basel, Switzerland. This article is an open access article distributed under the terms and conditions of the Creative Commons Attribution (CC BY) license (http://creativecommons.org/licenses/by/4.0/). 